Historic, archived document

Do not assume content reflects current scientific knowledge, policies, or practices. 


\section{Wholesale Trade List SPRING, 1924}
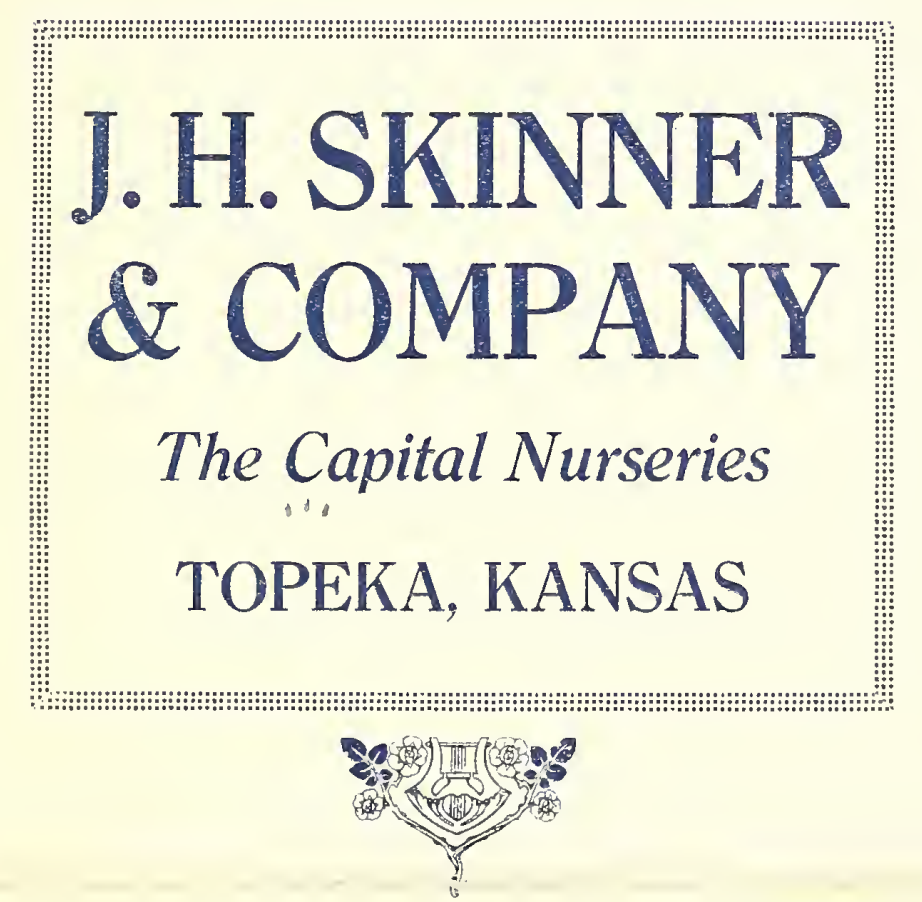

February 21, 1924

\section{TPRMS OP SAIT}

Prices herein alle net, no tiscumnt. Panling at cont.

All goods are forwarded at purchaser's risk.

Claims for "rror's, heductions. et"; must be made within ten days after goods arrive at destination to receive attention.

We guarantee stock to be true to name and in goor condition when it leaves oru grounds.

While we exercise the greatest care to have every tree or plant true to llame, and ale ready. on proper proots, to replace anything sent out loy us that may prove montrue to lahel, free of charge or refund the money paid for it. it is undexstood and agreen. between purchaser and onrselves, that we alre not to be held liable for nuy greater smm than that paid us for said trees that prove untrue.

All orders are accepted un condition that they shall he roid slould injury befall the stock from frost, hail, fire, or other "allses orer which we have no control.

Prices subject to change without notice.

Certificate of inspection with each shipment. 


\section{Fruit Tree Seedlings}

The Apple and Pear stocks offered below were frequently and carefully sprayed throughout the growing season, and handled carefully at digging time. We guarantee them to give satisfaction.

The Japan Pear are unusually good. The foliage was perfect throughout the season. The stand was good, consequently seedlings are not overgrown. Nice even grades, sure to please you.

API No, 1, 3 . .$\$ 12.00$

No. $1, \frac{3}{16}$-inch and up, branched roots .......... 12.00

No. $2,2 \frac{1}{2} / 16$ to $3 \frac{1}{2} / 16$-inch, straight roots ....... 8.00

Special grade, $\frac{3}{16}$-inch and up, short roots, suitable for

whole root grafting or for budding .......... 8.00

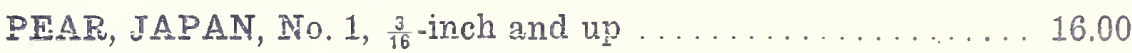

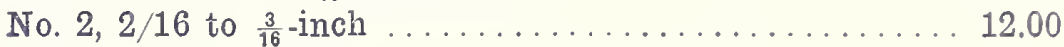

No. 3 , about $2 / 16$-inch ................... 8.00

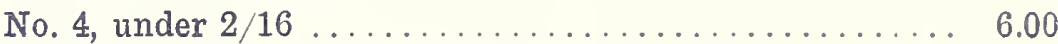

MAHALEB, French grown, 5 to $9 \mathrm{~mm} . \ldots \ldots \ldots \ldots . \ldots \ldots$

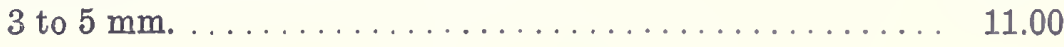

\section{ROOT GRAFTS.}

APPLE and CRAB, No. 1, Piece Root-

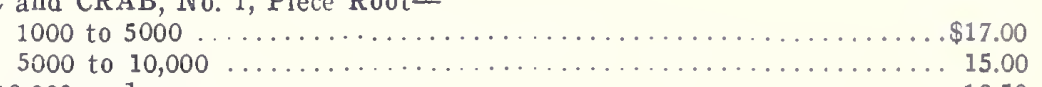

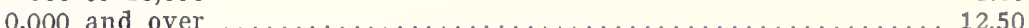

APPLE and CRAB, Whole Root-

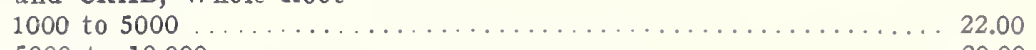

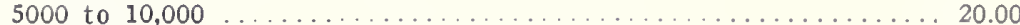

10,000 and over ....................................... 18.00

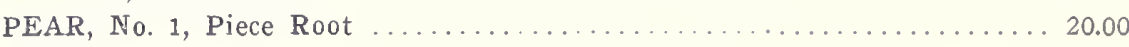

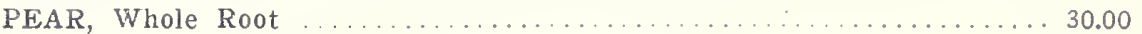

\begin{tabular}{|c|c|c|}
\hline Astrachan & Jonathan & Starman's Winesap \\
\hline Banana & Jumbo & Sweet June \\
\hline Ben Davis & Liveland & Talman's sweet \\
\hline Delicious & M. Blush & Wagener \\
\hline Duchess & MeIntosh & Wealthy \\
\hline Early Harvest & M. P. Twig & Tinesap \\
\hline Fameuse & N. IT. Greening & Willow Twig \\
\hline trano & l'aragon & Lellow Transparent \\
\hline Goodhue & Red June & Vellow Horse \\
\hline Grimes Golden & Red Wing & Lork Imperial \\
\hline Ingram & Rone Beauty & \\
\hline \multirow{3}{*}{ Hyslop } & CRAB APPLE & \multirow{3}{*}{ Whitney } \\
\hline & Florence & \\
\hline & PEAR GRAFTS & \\
\hline Bartlett & ('apps Favorite & \\
\hline lieurie de Anjou & liarber & Howell \\
\hline Fose & & etter \\
\hline
\end{tabular}

1 inch and up, 5 to 6 feet

is to $1 \frac{1}{6}$ inch, 4 to 6 feet

${ }_{10}^{7} \sigma$ to it inch, 4 to $5 \mathrm{feet}$

if to $]^{7}$ inch, 3 to 4 feet

APPLE-2 Years.

Astrachan

Duchess

Delicions:

Early Harvest.

Gano

krinses Golden

lngram

. Torlathan

Jiveland

M. Blusl

M. B. Twig

Paragon

Red Jume

Fiome lieduty

Stayman's linesalp

sweet June

Talman's sweet

IVillow Twig

ITinesal

Lellow Transparent

York imperial

arieties of Apple Grafts.

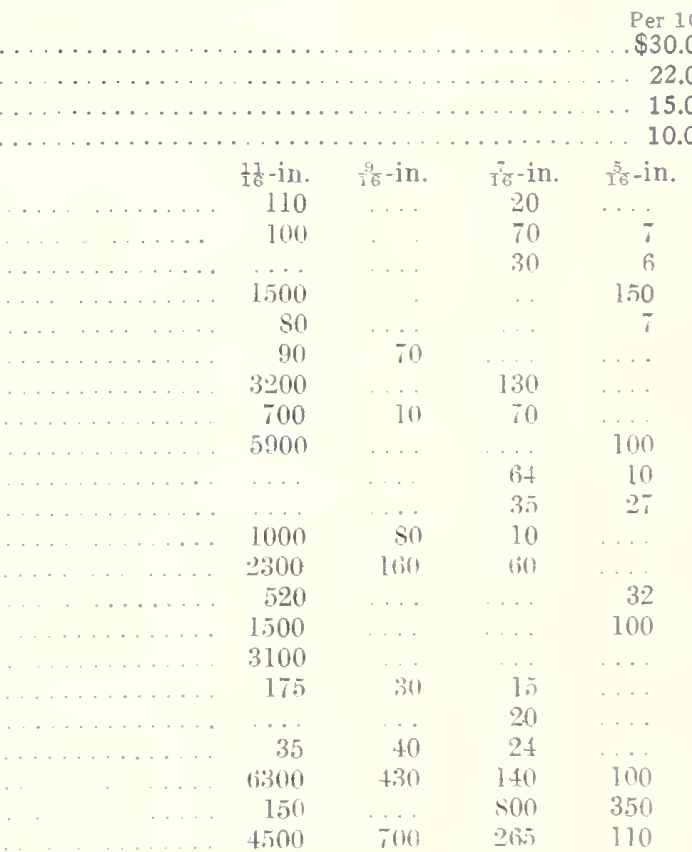

CRABS 
PEACH-1 Year.

$x \mathrm{X}, 5$ reet and up

if incli and up, 5 feet and up

is to 12 inch, 4 feet and up

${ }_{16}$ to $1 \mathrm{y}$ inch, 3 feet and up

is to $\frac{7}{16}$ inch, 2 feet and up

Alexander
Belle of leorgia
Champion

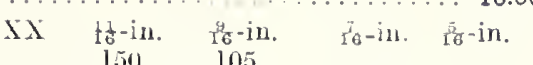

$\begin{array}{lllll}\ldots & 150 & 105 & 100 & \cdots \\ 200 & \cdots & \cdots & 1500 & +5\end{array}$

Crawford's Early

Crawford's Late

Elberta

litzgerald

… 1

200

1000

Greensboro

‥ 110

35100

380

Heath Cling

50 30

…

380

Indian Blood Cling.

Lemon Cling

Mayflower

salway

$35 \quad 50$

500

i5

15
40

$75 \quad 100$

115

CHERRY - 2 Years.

$\frac{1}{16}$ inch and up, 4 feet and up

产 to $\frac{1}{1} \frac{1}{6}$ inch, $3 \frac{1}{2}$ feet and up

Per 100 $\$ 50.00$ . . . . . . . . . . 40.00

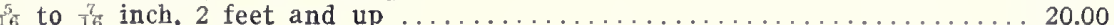

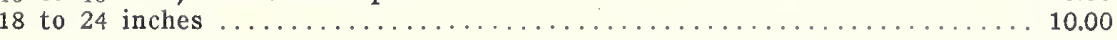

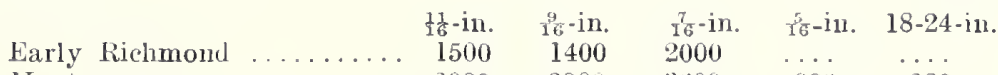

$\begin{array}{llllll}\text { Montmorency . . . . . . . . . } & 2000 & 3000 & 3600 & 900 & 280\end{array}$

KIFFFER AND GARBER PEAR-2 Years. J'er 100

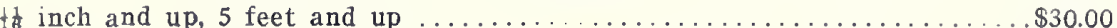

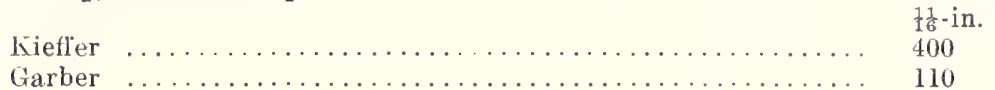

BARTLETT PEAR-2 Years.

10

te inch and up, 5 feet and up

g to if inch, 4 feet and up.

Per 100

$\frac{7}{16}$ to inch, $31 / 2$ feet and up

45.00

30.00

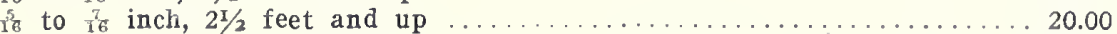

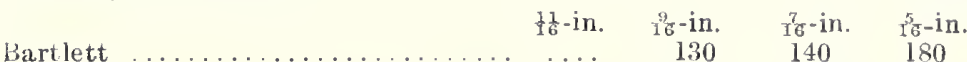

BARTLETT PEAR-1 Year. Per 100 (Branched)

ftinch and up, 5 feet and up

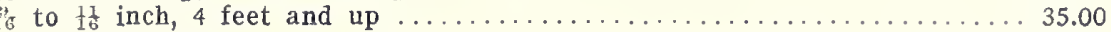

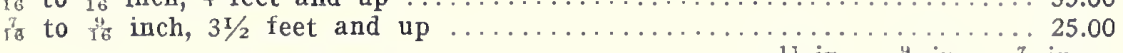

Bartlett.

$\begin{array}{ccc}\frac{1}{16}-\text { in. } & \frac{7}{16}-\text { in. } & \frac{7}{16}-\text { in. } \\ 47 & 140 & 30\end{array}$

PEAR-1 Year.

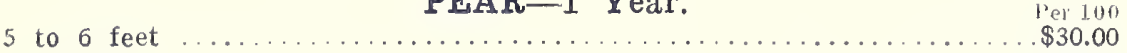

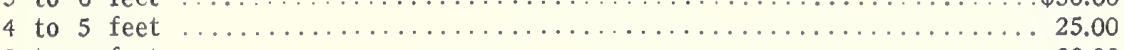

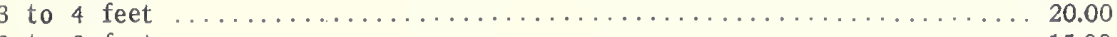

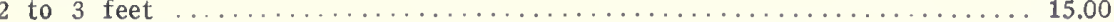

Bartlett 5-6 ft. $t-5 \mathrm{ft} . \quad 3-4 \mathrm{ft} .2-3 \mathrm{ft}$

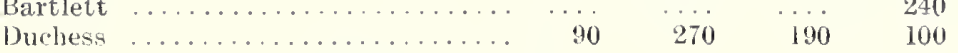

5 to 6 feet

PEAR-1 Year

Per 100 $\$ 18.00$

4 to 5 feet

3 to 4 feet

14.00

2 to 3 feet

(ravber

$5-6 \mathrm{ft} . \quad 4-5 \mathrm{ft} . \quad 3-1 \mathrm{ft} . \quad 2-3 \mathrm{ft}$.

$610 \quad 336 \quad 95$

PIUM (on Plum).

Per 100 $\$ 60.00$

$\frac{1}{6}$ inch and up

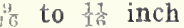

${ }^{6} \mathrm{~s}$ to $\frac{1}{16}$ inch

if to ${ }^{\frac{1}{6}}$ inch

Burbank

Alundance

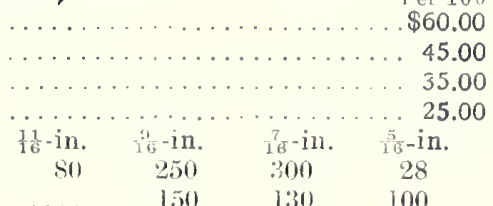

PLUM (on Plum).

$\frac{1}{16}$ inch and up

if to $\frac{11}{16}$ inch

7 to $\frac{9}{16}$ inch

5 to inch

Burwood

Sapa

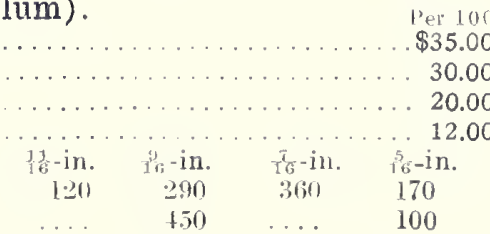

APRICOT (on Plum).

100

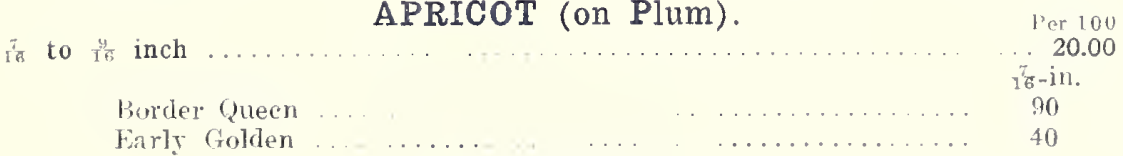

GOOSEBERPY.

Houghton, 2 years, No. 1 
GRAPE.

Concord, 2 years, No. 1

Concord, 1 year, No. 1

Worden, 2 years, No. 1

\section{GRAPE CUTTINGS.}

PEe: 1004 $\$ 2.75$ 4.25 3.75 3.25

\section{CURRANTS.}

Fay's, 1 year, No. 1 London Market, 1 year, No.

Perfection, 1 year, No. 1

RHUBARB, Myatt's Linnaeus.

Divided Roots

\section{FORPST TREE SEEDLINGS}

CATAIPA SPECIOSA, 18 to 24 inches

12 to 18 inches

6 to 12 inclies

12 to 18 inches

HONEY, 6 to 12 inches ............................ 2.50

LOCUST, HONEY (Grown from seed from thornless trees).

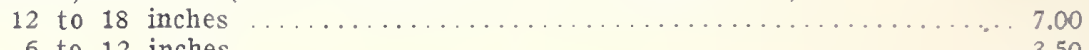

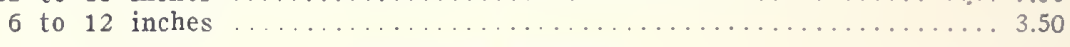

SHADE TREES.

ASH, 6 feet and up

5 to 6 feet.

1 to $1 \frac{1}{4}$ inches

BECHTDL'S-Flowering Crab.

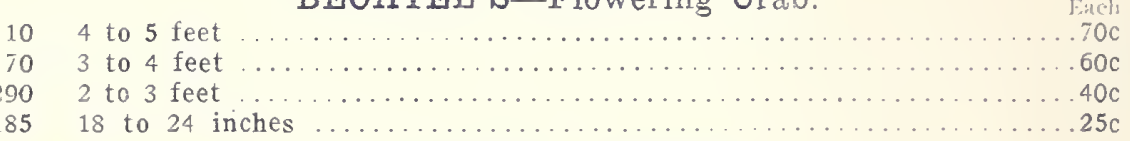

\section{FLOWERING SHRUBS}

CORNUS SIBERICA, 2 to 3 feet

18 to 24 inches

TIIA, PRIDE OF ROCHESTER, 2 to 3 feet ............. 1.80

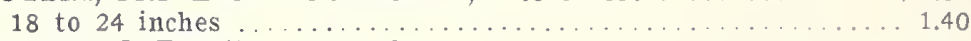

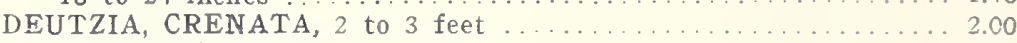

18 to 24 inches

FORSYTHIA FORTUNEI, 3 to 4 feet ...................... 2.50

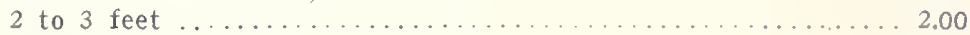

FORSYTHIA SUSPENSA, 3 to 4 feet ....................... 2.50

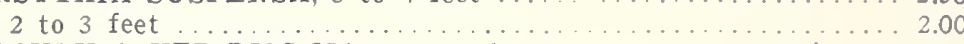

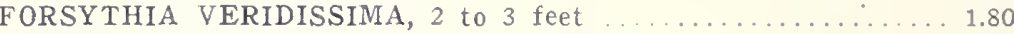

1.40

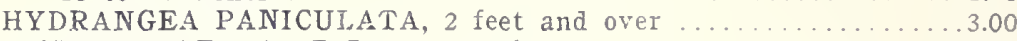

LONICERA BELLA ABIDA, 4 to 5 feet . . . . . . . . . . . . 2.50

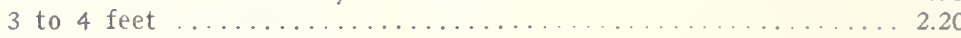

LONICERA CHRYSANTHA, 4 to 5 feet .................... 2.75

JONICERA GRANDIFLORA, 3 to 4 feet ................ 2.75

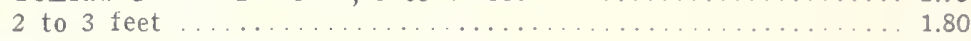

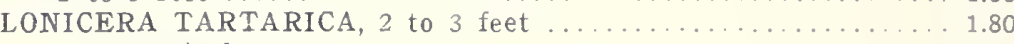

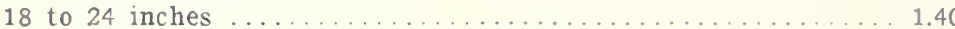

LILAC, COMMON PURPLE, 3 feet and over .............. 2.75

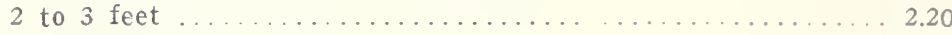

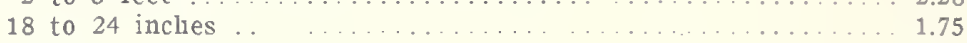

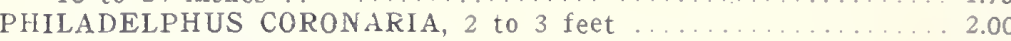

.

PIILADELPHUS GRANDIFLORA, 4 to 5 feet ............ 3.00

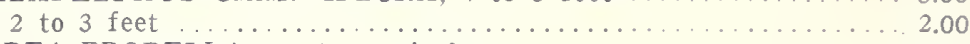

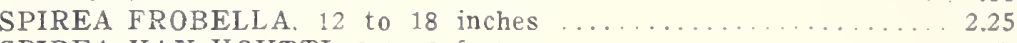

SPIREA VAN HOUTTI, 2 to 3 feet ......................... $1.50 \quad 12.00$

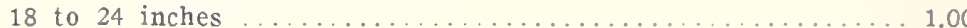

12 to 18 inches

TAMARIX HISPIDA, 3 to 4 feet

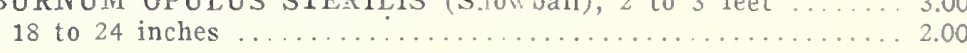

\section{ROSES.}

200 American Beauty, No. 1

VINES-2 Years, No. 1. Per 10

AMPELOPSIS ENGELMANI

CELASTRUS SCANDENS (American Bitter Sweet)

CLEMATIS COCCINNEA

CLEMATIS PANICULATA

LONICERA, HALLEANA (Hall's Japan Honeysuckle)

7.00

$100 \quad$ Per 1000
$3.50 \$ \$ 30.00$

PRIVET-Amoor River North.

20002 to 3 feet, 4 canes and over

5002 to 3 feet, 2 and 3 canes

3000 One year, 18 to 24 inches, 2 and 3 canes

7000 One year, 12 to 18 inches, 2 and 3 canes

(1)(11)

101011 .00 .00 0

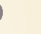

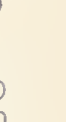

$20 \mathrm{C}$

c

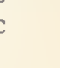

